\title{
PENGEMBANGAN DISAIN PEMBELAJARAN MATERI BANGUN RUANG BERBASIS REALISTIC MATHEMATICS EDUCATION UNTUK MENINGKATKAN KEMAMPUAN BERPIKIR KRITIS MATEMATIS SISWA
}

\author{
ELITA ZUSTI JAMAAN \\ Jurusan Matematika FMIPA UNP Padang Indonesia \\ elita.jamaan@gmail.com \\ 081382953173
}

\section{PENDAHULUAN}

Pokok bahasan matematika yang diajarkan di SMP dan di SMA salah satunya adalah bangun ruang. Walaupun bangun ruang telah diajarkan sejak SD, namun ternyata kemampuan siswa dalam menyelesaikan soal-soal dimensi tiga masih perlu ditingkatkan. Materinya bersifat abstrak, banyak menggunakan konsep, dan bukan materi hafalan,sehingga banyak siswa belum menguasai konsep materi dan mengalami kesulitan dalam mengerjakan soal - soal pada materi bangun ruang. Seringkali siswa hanya menghafal rumus tanpa memahami maknanya dalam kehidupan sehari-hari. Siswa lemah dalam geometri, khususnya dalam pemahaman ruang dan bentuk (Suwaji, 2008, p. 1).

Permasalahan yang menyangkut pembelajaran geometri, yang dapat ditanggulangi guru adalah kendala yang bersumber dari guru itu sendiri: mulai dari kurangnya inisiatif guru dalam merancang pembelajaran yang sesuai dengan tingkat intelektual siswa, tidak berupayanya guru dalam menciptakan pendekatan pembelajaran, Salah satu usaha yang dapat dilakukan guru di sini adalah mengembangkan disain pembelajaran dengan Pendekatan Matematika Realistik (PMR)/Realistic Mathematics Education (RME). Pendekatan PMR membahas secara khusus bagaimana seharusnya pembelajaran geometri dilaksanakan dalam geometri realistik. De Moor (dalam Fauzan: 2002) Pendekatan matematika realistik dapat dijadikan sebagai jembatan untuk meningkatkan kemampuan berpikir kritis matematis siswa Peningkatan kemampuan berpikir kritis matematis akan diperoleh dari pengalaman mereka selama mengikuti serangkaian aktivitas yang didisain guru pada kegiatan pembelajaran dengan berbasis pendidikan matematika realistik.

Dalam kurikulum nasional di Indonesia, dari tingkat sekolah dasar sampai sekolah menengah atas siswa dituntut untuk dapat menguasai materi geometri bidang dan bangun ruang. Salah satu cara untuk memecahkan permasalahan tersebut adalah dengan menciptakan disain belajar. Dalam membuat disain belajar guru juga perlu mempertimbangkan alur berpikir siswa yang berkembang selama kegiatan belajar dan membuat antisipasi terhadap apa yang akan terjadi. Hal ini perlu dibuat agar dalam pelaksanaannya guru tidak mengabaikan ragam pemikiran siswa. Salah satu cara yang dapat dilakukan adalah dengan membuat sebuah alur pembelajaran. Menurut Simon (1995) alur pembelajaran terdiri dari tiga komponen, yaitu tujuan untuk pembelajaran bermakna, sekumpulan tugas untuk mencapai tujuan, dan hipotesis tentang bagaimana siswa belajar dan begaimana siswa berpikir.

Berdasarkan uraian tersebut diperlukan sebuah disain pembelajaran yang dapat membuat siswa memahami konsep bangun ruang dan meningkatkan kemampuan berpikir kritis siswa. 
Selain itu, dibuat juga rancangan dugaan alur berpikir siswa beserta antisipasinya. Dalam perancangannya alur pembelajaran tidak sama seperti rencana pembelajaran yang dibuat guru. Alur pembelajaran memuat tujuan khusus kegiatan belajar yang selanjutnya dilengkapi dengan sekumpulan aktivitas untuk mencapai setiap tujuan yang dirumuskan. Pada setiap aktivitas yang dirancang dibuat beberapa hipotesis tentang apa yang akan dilakukan siswa. Untuk kegiatan siswa yang tidak sesuai akan dibuat antisipasi-antisipasi yang mengarahkan siswa pada penyampaian tujuan yang diharapkan. Dengan disain alur pembelajaran diharapkan kegiatan belajar lebih dinamis.

Peneliti menganggap penting pengembangan disain pembelajaran bangun ruang, karena dengan dikembangkannya disain pembelajaran bangun ruang menggunakan pendekatan matematika realistik, diharapkan siswa terlibat secara aktif dan menggali informasi sebanyakbanyaknya untuk meningkatkan kemampuan berpikirnya sendiri, sehingga siswa dapat memahami konsep matematika untuk digunakan dalam menyelesaikan permasalahan. Peran guru sebagai fasilitator sangat diperlukan dalam memberikan siswa dukungan dan tantangan dalam mempelajari matematika (NCTM, 2000, p.16). Guru juga perlu merencanakan kegiatankegiatan yang menarik yang akan dilakukan siswa serta mempersiapkan alur pembelajaran sebelum pelajaran dimulai (Frei, 2008, p.61).

Berdasarkan uraian di atas, tujuan dari penelitian ini adalah menghasilkan disain pembelajaran (Local Instructional Theory/LIT) bangun ruang berbasis Realistic Mathematisc Education (RME) yang memenuhi kriteria valid, dan mengimplementasikan desain pembelajaran bangun ruang terhadap kemampuan berpikir kritis matematis siswa SMPN di Padang.

Pembelajaraan matematika di kelas ditekankan pada keterkaitan antara konsep-konsep matematika dengan pengalaman siswa sehari-hari. Terkait dengan hal ini Freudenthal (1991) mengatakan bahwa, bila siswa terpisah dari pengalaman mereka sehari-hari, maka siswa akan cepat lupa dan tidak dapat mengaplikasikan matematika. Salah satu pembelajaran matematika yang dimulai dari pengalaman peserta didik sehari-hari dan menerapkan matematika dalam kehidupan sehari-hari adalah pembelajaran matematika realistik. Pembelajaran ini dilandasi oleh konsep Freudenthal (1991) yaitu matematika harus dihubungkan dengan kenyataan, berada dekat dengan peserta didik, relevan dengan kehidupan masyarakat, dan materi-materi harus dapat ditransmisikan sebagai aktivitas manusia. Ini berarti materi-materi matematika harus dapat menjadi aktivitas peserta didik dan memberikan kesempatan kepada peserta didik untuk menemukan matematika melalui praktek yang dilakukan sendiri dan sesuai dengan level kognitif peserta didik.

Peserta didik perlu dituntun menuju dunia matematika dengan jembatan penghubung yang disebut dengan matematisasi. Menurut Freudhental (dalam Gravemeijer, 1994), aktivitas maematika berarti dikaitkan dengan realitas melalui situasi masalah. Istilah "realitas" berarti bahwa situasi masalah sebaiknya nyata ditunjukkan kepada peserta didik. Sehingga apa yang mereka pelajari tidak lagi menjadi sesuatu yang abstrak, tetapi menjadi konkrit bagi peserta didik. Dalam Real Mathematics Education(RME), matematika dipandang sebagai aktivitas insani (human activity), sehingga kegiatan pembelajaran dilakukan dengan menggunakan konteks nyata dan menghargai gagasan-gagasan peserta didik dalam mengerjakan masalahmasalah matematika. Merujuk pada pendapat Freudenthal dalam Wijaya (2012:20), "Matematika sebaiknya tidak diberikan kepada peserta didik sebagai suatu produk jadi yang siap pakai, melainkan sebagai suatu bentuk kegiatan dalam mengkonstruksi konsep matematika". Oleh karena itu matematika harus diartikan dengan realita dan matematika merupakan aktivitas 
manusia. Pernyataan tersebut merupakan landasan pengembangan pendekatan RME.

Pendekatan RME juga menekankan untuk membawa matematika pada pengajaran bermakna dengan mengkaitkannya dalam kehidupan sehari-hari yang bersifat realistik. Peserta didik disajikan masalah-masalah kontekstual yaitu masalah-masalah yang berkaitan dengan situasi realistik. Dalam pendidikan matematika, realistik bermakna pembelajaran matematika yang berbasis masalah dalam kehidupan sehari-hari. Dalam pembelajaran dengan pendekatan RME, urutan atau alur pembelajaran tersebut dibalik, artinya untuk mempelajari suatu fakta, konsep, keterampilan, atau prinsip, peserta didik diberikan masalah sehari-hari yang sering dijumpainya. Melalui penyelesaian masalah tersebut guru memfasilitasi peserta didik untuk mengembangkan pengetahuan mereka.

Sebuah alur pembelajaran memberikan petunjuk bagi guru untuk menentukan dan merumuskan tujuan-tujuan pembelajaran yang akan dicapai. Selanjutnya guru dapat membuat keputusan-keputusan tentang langkah-langkah yang akan ditempuh dalam pembelajaran, guru seharusnya memiliki terlebih dahulu informasi tentang pengetahuan prasyarat, strategi berfikir yang digunakan anak, level berfikir yang mereka tunjukkan dan bagaimana variasi aktivitas yang dapat menolong mereka mengembangkan pemikiran yang dibutuhkan untuk tujuannya tersebut. Semuanya termuat dalam hipotesis learning trajectory. Menurut Rangkuti (2015) informasiinformasi itu dapat diperoleh melalui observasi, pretes, atau penilaian lain. Berdasarkan observasi, penilaian, dan informasi lain yang telah dikumpulkan, guru dapat mengetahui learning trajectory ataupun tingkat berfikir yang dimiliki anak saat itu. Dengan mengetahui level dan alur pikir yang dimiliki anak, dalam proses pembelajaran kita dapat mengetahui mana yang harus didahulukan dalam proses pengembangannya. Learning trajectory memberikan suatu kerangka kerja bagi guru untuk mengembangkan pengetahuan tentang berpikir dan belajar peserta didik. Selanjutnya pengetahuan tentang berpikir dan belajar peserta didik dapat digunakan untuk merencanakan pembelajaran.

Berpikir kritis matematis adalah berpikir kritis pada bidang ilmu matematika. Dengan demikian, berpikir matematis adalah proses berpikir kritis yang melibatkan pengetahuan matematika, penalaran matematika dan pembuktian matematika. Berpikir kritis dalam matematika merupakan kemampuan berpikir kritis dalam menyelesaikan masalah matematika. Berdasar pada definisi-definisi berpikir kritis yang dikemukakan para ahli, dalam penelitian ini dikembangkan indikator berpikir kritis matematis, yang diklassifikasikan atas lima komponen berpikir kritis, yaitu Analisis, meliputi: Memisahkan informasi ke bagian-bagiannya, Mencari hubungan antar informasi, Mengorganisasikan informasi Evaluasi, meliputi: Membuat criteria, Menentukan kerasionalan suatu jawaban,Menilai suatu argument. Pembuktian, meliputi: Memberikan alasan yang logis, Menyediakan bukti pendukung, Menentukan konsep yang termuat dalam membuktikan. Pemecahan Masalah, meliputi: Membuat strategi pemecahan masalah, Menjalankan strategi pemecahan masalah, Mengevaluasi kebenaran hasil pemecahannya. Menemukan Analogi, meliputi: (1) Melihat keserupaan, (2) membuat kesimpulan atas dasar keserupaan.

\section{TUJUAN PENELITIAN}

1. Menghasilkan disain pembelajaran bangun ruang berbasis Realistic Mathematics Education (RME) yang memenuhi kriteria vali, praktis dan efektif.

2. Mengimplementasikan disain pembelajaran bangun ruang terhadap kemampuan berpikir kritis matematis siswa. 


\section{METODE PENELITIAN}

Berdasarkan tujuan yang ingin dicapai, penelitian ini menggunakan salah satu jenis penelitian pengembangan yakni Design Research (DR) versi Gravemeijer and Cobb (2013) dengan tiga fase pelaksanaan penelitian dari pandangan desain pembelajaran, yaitu preparing for the experiment, conducting the experiment, and retrospective analyses. Tahap pertama atau fase pertama adalah Preparing for the Experiment (Tahap Persiapan). Tujuan dari preparing phases adalah untuk merumuskan sebuah dugaan alur belajar yang dapat diperluas/diuraikan dan diperbaiki ketika pelaksanaan desain eksperimen (Gravemeijer and Cobb, 2013). Untuk membuat sebuah disain pembelajaran bangun ruang dilakukan review literatur.

Tahap pertama merancang disain alur pembelajaran yang telah diujicobakan dan dianalisis disebut Local Instructional Trayektory (LIT). Alur pembelajaran dalam penelitian ini beirisi tentang alur belajar yang difokuskan pada serangkaian aktivitas pengembangan pemahaman siswa terhadap materi bangun ruang beserta dugaan aktivitas yang dilakukan siswa dan antisipasi yang akan dilakukan dalam proses belajar bangun ruang (Gravemeijer, 2013). Rencana alur belajar yang telah dirancang digunakan untuk tahap eksperimen. Peneliti merancang beberapa aktivitas belajar sebagai rencana alur belajar yang dapat membantu siswa untuk memahami bangun ruang.

Setelah tahap perancangan alur pembelajaran, dilakukan validasi kepada ahli. Ahli disini diutamakan pada ahli RME dan materi bangun ruang. Validasi dilakukan pada tiga orang ahli pendidikan matematika. Setelah alur pembelajaran yang dirancang dinyatakan valid, kegiatan dilanjutkan dengan pelaksanaan eksperimen.

Tahap kedua adalah pelaksanaan eksperimen. Menurut Gravemeijer dan Cobb (2013) tujuan tahap ini adalah untuk menguji dan memperbaiki dugaan disain belajar yang telah dikembangkan pada tahap persiapan dan perancangan, serta melihat bagaimana LIT bekerja. Pada tahap ini, desain alur belajar digunakan sebagai petunjuk (Guideline) pelaksanaan kegiatan belajar. Pelaksanaan tahap ini dilakukan pada siklus preliminary teaching experiment, ditujukan untuk melihat bagaimana desain pembelajaran bekerja dan dievaluasi yang dilaksanakan di kelas.

Tujuan utama tahap pembelajaran eksperimen adalah untuk menguji dugaan yang telah dirancang untuk proses belajar bangun ruang. Tahap ini dilaksanakan pada kelas di SMPN atau di SMA di Padang. Pemilihan siswa dilakukan oleh guru kelas karena guru matematika dapat mengetahui kemampuan siswa secara umum. Data dikumpulkan dengan catatan lapangan, dan hasil kerja siswa. Catatan lapangan terdiri dari dua bagian. Bagian deskriptif yang merupakan bagian yang berisi deskripsi tentang semua peristiwa dan pengalaman yang didengar dan dilihat. Bagian yang kedua adalah refleksif, yaitu bagian yang berisi masalah yang terjadi, ide dari pengamat, sesuatu yang mengarahkan, kesan, dan prasangka (Moleong, 2011). Catatan lapangan dalam penelitian ini digunakan untuk membantu dalam menjelaskan hasil penelitian sekaligus alat yang digunakan sebagai bahan perbaikan alur belajar.

Pretes dan postes dilakukan pada siswa kelas eksperimen. Sesuai dengan fungsinya pretes dilakukan sebelum kegiatan belajar dilakukan dan postes dilakukan setelah kegiatan belajar dilakukan. Soal matematika untuk pretes dan postes dibuat sama. Soal yang dibuat merupakan soal untuk mengukur kemampuan berpikir kritis matematis siswa. Soal dirancang berdasarkan indikator kemampuan berpikir kritis matematis. Hal ini dikarenakan salah satu tujuan penelitian ini adalah untuk mendeskripsikan kemampuan kemampuan berpikir kritis matematis siswa. 
Tabel .1.Teknik Pengumpulan Data

\begin{tabular}{|l|l|l|l|}
\hline No & \multicolumn{1}{|c|}{$\begin{array}{c}\text { Teknik } \\
\text { Pengumpulan Data }\end{array}$} & \multicolumn{1}{|c|}{ Sasaran } & \multicolumn{1}{|c|}{$\begin{array}{c}\text { Alat } \\
\text { Pengumpul } \\
\text { Data }\end{array}$} \\
\hline 1 & Catatan Lapangan & $\begin{array}{l}\text { Membantu dalam menjelaskan } \\
\text { hasil penelitian sekaligus alat } \\
\text { yang digunakan sebagai bahan } \\
\text { perbaikan disain belajar }\end{array}$ & $\begin{array}{l}\text { Lembar catatan } \\
\text { lapangan }\end{array}$ \\
\hline 2 & Pretes dan Postes & $\begin{array}{l}\text { Untuk mengetahui kemampuan } \\
\text { berpikir kritis matematis } \\
\text { sebelum dan sesudah } \\
\text { penerapan desain } \\
\text { pembelajaran. }\end{array}$ & $\begin{array}{l}\text { Lembar tes } \\
\text { berpikir kritis } \\
\text { matematis }\end{array}$ \\
\hline
\end{tabular}

Instrumen yang digunakan dalam penelitian ini adalah lembar tes yang merupakan tes untuk melihat kemampuan berpikir kritis matematis siswa. Tes kemampuan berpikir kritis matematis dilakukan pada tahap pre - post test. Pada kegiatan validasi digunakan instrumen validasi. Semua data yang diperoleh dalam penelitian ini akan dianalisis secara kualitatif.

Analisis data hasil pretes siswa bertujuan untuk memberikan informasi tentang pengetahuan siswa mengenai bangun ruang. Analisis data dilakukan secara kualitatif dengan menggunakan hasil setiap item soal sebagai petunjuk. Hasil analisis ini digunakan sebagai bahan pertimbangan dalam menyusun dan memperbaiki alur belajar. Hasil postes dianalisis secara kualitatif. Tujuan analisis ini adalah untuk menyelidiki dampak kemampuan kemampuan berpikir kritis matematis siswa setelah dilakukan pembelajaran. Analisis dilakukan dengan melihat indikator kemampuan berpikir kritis matematis siswa. Hasil analisis postes ini digunakan untuk mengetahui dan mendeskripsikan kemampuan berpikir kritis matematis siswa.

\section{ANALISIS DATA PENELITIAN DAN PEMBAHASAN}

Pada tahap ini dilakukan pengkajian literatur-literatur tentang bagaimana cara mengajar materi bangun ruang. Literatur yang dikaji berupa jurnal dan buku panduan sebagai acuan dalam mengajarkan topik bangun ruang. Selain mengkaji literatur, juga dilakukan analisis terhadap siswa. Siswa diberikan masalah kontekstual dengan tujuan agar siswa lebih mudah untuk mempelajari materi dengan baik. Dengan demikian perlu dikembangkan alur belajar dengan pendekatan Realistic Mathematics Education.

Alur belajar yang dirancang difokuskan pada pengembangan pemahaman dan kemampuan berpikir kritis siswa. Hasil pengembangan alur belajar yang sudah dilakukan menyatakan bahwa aktivitas yang sudah dirancang dapat mengarahkan siswa untuk memahami konsep bangun ruang dari tahap informal ke tahap formal.

Semua produk yang telah dirancang divalidasi oleh tiga orang dosen matematika. Hasil validasi dari tiga orang validator diolah dan dirata-ratakan untuk menentukan kriteria kevalidan perangkat yang dibuat. Validasi yang dilakukan bertujuan untuk melihat efek potensial alur pembelajaran terhadap kemampuan berpikir kritis siswa. Kegiatan validasi dilakukan dalam bentuk mengisi lembar validasi dan diskusi sehingga dirancang alur belajar yang valid dan layak untuk dikembangkan. Berikut merupakan tabel validasi yang akan dilakukan oleh tiga orang dosen matematika. 
Tabel 2. Validasi Disain Pembelajaran

\begin{tabular}{|c|c|c|c|c|c|c|c|c|}
\hline \multirow{2}{*}{ No } & \multirow{2}{*}{ Aspek yang dinilai } & \multicolumn{3}{|c|}{$\begin{array}{l}\text { Penilaian } \\
\text { Validator }\end{array}$} & \multirow{2}{*}{ Skor } & \multirow{2}{*}{$\begin{array}{l}\text { Rata } \\
\text { Rata } \\
\text { Item }\end{array}$} & \multirow{2}{*}{$\begin{array}{l}\text { Rata } \\
\text { Rata } \\
\text { Tiap } \\
\text { Aspek }\end{array}$} & \multirow{2}{*}{$\begin{array}{c}\text { Kategor } \\
\mathrm{i}\end{array}$} \\
\hline & & 1 & 2 & 3 & & & & \\
\hline 1 & 2 & 3 & 4 & 5 & 6 & 7 & 8 & 9 \\
\hline \multirow[b]{2}{*}{1} & Isi & & & & & & & \\
\hline & $\begin{array}{l}\text { Ketepatan aktivitas } \\
\text { dalam setiap pertemuan } \\
\text { yang mengarahkan } \\
\text { kepada penemuan Local } \\
\text { Instructional Theory } \\
\text { (LIT). }\end{array}$ & & & & & & & \\
\hline 2 & $\begin{array}{l}\text { Ketepatan aktivitas } \\
\text { setiap pertemuan yang } \\
\text { diawali dari } \\
\text { matematisasi horizontal } \\
\text { (informal) dan diikuti } \\
\text { oleh masalah realistik } \\
\text { yang membawa kepada } \\
\text { matematisasi vertikal } \\
\text { (formal) }\end{array}$ & & & & & & & \\
\hline 3 & $\begin{array}{l}\text { Ketepatan soal dalam } \\
\text { memperkenalkan } \\
\text { konsep bangun ruang }\end{array}$ & & & & & & & \\
\hline 4 & $\begin{array}{l}\text { Kebenaran sajian materi } \\
\text { yang runtut dan } \\
\text { sistematis }\end{array}$ & & & & & & & \\
\hline 5 & $\begin{array}{l}\text { Ketepatan HLT } \\
\text { bendasarkan prinsip- } \\
\text { prinsip RME } \\
\checkmark \text { Penemuan kembali } \\
\text { secara terbimbing } \\
\text { (guided reinvention) } \\
\text { dan matematisasi } \\
\text { progresif } \\
\quad \text { (progressive } \\
\text { mathematization) }\end{array}$ & & & & & & & \\
\hline & $\begin{array}{ll}\checkmark & \text { Fenomenologi } \\
\text { didaktik (didactical } \\
\text { phenomenology) } \\
\checkmark \\
\text { Pengembangan } \\
\text { model sendiri (self- } \\
\text { developed models) }\end{array}$ & & & & & & & \\
\hline
\end{tabular}




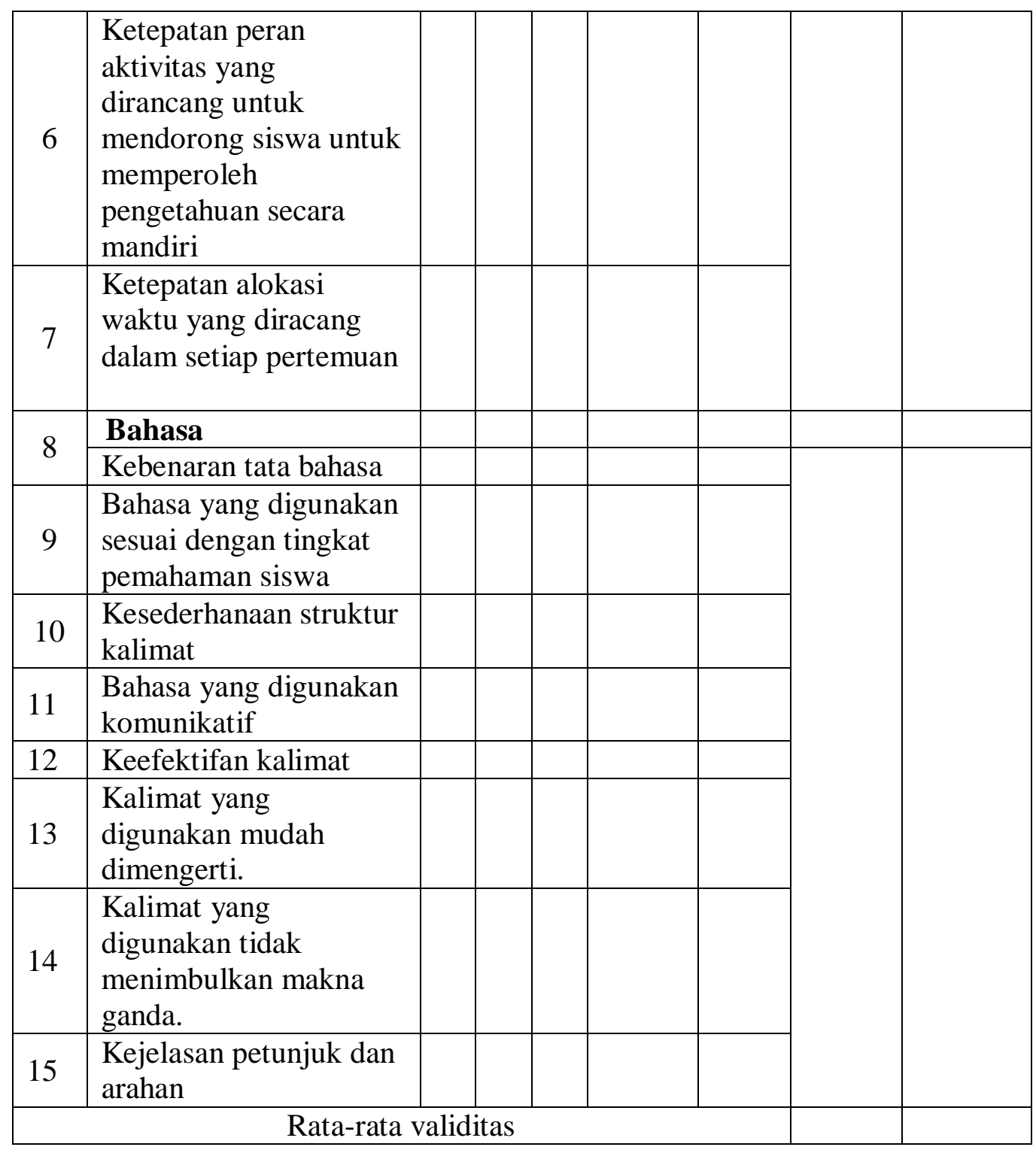

Berdasarkan Tabel 2 di atas, jika hasil validasi aspek isi dikategorikan valid, hal ini menunjukkan bahwa ketepatan aktivitas dalam setiap pertemuan yang mengarahkan kepada penemuan Local Instructional Theory (LIT). Jika hasil validasi aspek bahasa dikategorikan valid,.menunjukkan bahwa tata bahasa yang digunakan sudah benar, bahasa yang digunakan sesuai dengan tingkat pemahaman siswa, struktur kalimat sederhana, bahasa yang digunakan komunikatif, kalimat yang digunakan efektif, mudah dimengerti, dan tidak menimbulkan makna ganda. Jika hasil validasi menunjukkan semua valid maka alur belajar layak digunakan.

Analisis hasil tes dilakukan dengan melihat cara siswa dalam menyelesaikan soal tes kemampuan berpikir kritis matematis dan strategi yang digunakan sesuai dengan indikator yang telah ditetapkan. Hasil pre-test tidak dianalisis secara kuantitatif karena nilai pre-test tidak dibandingkan dengan nilai post-test. Analisis data hasil pre-test siswa bertujuan untuk memberikan informasi tentang pengetahuan awal siswa mengenai bangun ruang. Informasi ini digunakan untuk menentukan bagaimana hasil ini dihubungkan sebagai langkah awal kegiatan pembelajaran. Perkembangan kemampuan berpikir kritis matematis siswa pada setiap indikator 
dilihat dari hasil pre-test dan hasil post-test. Dari hasil analisis tersebut terlihat kemajuan yang ditunjukkan siswa dari awal hingga akhir pembelajaran.

Selanjutnya, hasil analisis post-test mendukung penambahan informasi dalam menggambarkan kesimpulan dari kegiatan pembelajaran eksperimen dan menjawab rumusan masalah penelitian yang kedua. Setelah dilakukan postest, selanjutnya dilakukan penilaian terhadap hasil yang diperoleh menggunakan rubrik penilaian berpikir kritis matematis..

Setelah fase preparing for the experiment selesai dilaksanakan maka akan dilanjutkan dengan fase conducting the experiment, dan jika waktu serta kondisi yang memungkin akan dilanjutkan dengan fase retrospective analyses.

\section{DAFTAR PUSTAKA}

[1] Clements, D.H \& Battista, J.M. 1992. Geometry and Spatial Reasoning. Hand Book of Research on Mathematics Teaching and Learning, New York: Macmillan Publishing Company

[2] Fauzan, Ahmad. 2002. Applying Realistic Mathematics Education (RME) InTeachingGeometry In Indonesian Primary Schools (Online) (http://core.kmi.open.ac.uk/download/pdf/11462400.pdf, diakses 23 Juni 2015).

[3] Frei, S. (2008). Teaching mathematics today. Huntington Beach: Shell Education.

[4] Freudenthal. 1991. Revisting Mathematics Education. China: Lectures Kluwer Academic.

[5] Gravemeijer, Koeno. 1994. Developing Realistic Mathematics Education. Utrecht: Freudenthal Institute.

[6] Gravemeijer, Koeno and Cobb, Paul. 2013. Design research from the Learning Design Perspective. Dalam Jan Ven Den Akker, et. al. Educational Design Research. London: Routledge.

[7] Moleong. (2011). Action Research

[8] NCTM. (2000). Handbook of Research on Mathematics Teaching and Learning, Editor: Douglas A. Grows. USA: Macmillan Library Reference.

[9] Rangkuti, Ahmad Nizar. 2015. Pengembangan Alur Pembelajaran Topik Pecahan di Sekolah Dasar dengan Pendekatan Pendidikan Matematika Realistik. Padang: Program Pascasarjana UNP.

[10] Simon,M.A.(1995). Reconstructing Mathematics Pedagogy from a Constructivist Perspective.Journal for Research in Mathematics Education, 26(2), 114-145. (Online). (http://www.math.ntnu.Edu.tw, diakses 23 Juni 2015).

[11] Suwaji, U.T. (2008). Permasalahan pembelajaran geometri ruang SMP dan alternative pemecahannya. Yogyakarta: P4TK 